\title{
Evaluation of Temporomandibular Disorders with Research Diagnostic Criteria; In A Turkish Patient Population
}

\section{Emre Mumcu $^{1 *}$ and Merve Kayis ${ }^{2}$}

${ }^{1}$ Associate Professor, Eskisehir Osman Gazi University, Faculty of Dentistry, Department of Prosthodontics Eskisehir, Turkey

${ }^{2}$ Specialist at Prosthodontics, Turkey

*Corresponding Author: Emre Mumcu, Associate Professor, Eskisehir Osman Gazi University, Faculty of Dentistry, Department of

Prosthodontics Eskisehir, Turkey.

Received: October 04, 2019; Published: October 15, 2019

DOI: $10.31080 /$ ASDS.2019.03.0670

\begin{abstract}
Objective: The objective of this study is to investigate the frequency of signs and symptoms of Temporomandibular Disorders (TMD) on patients who have referred to the Eskisehir Osman Gazi University Faculty of Dentistry Department of Prosthodontics.

Materials and Methods: After our patients answered the questionnaire, the symptoms and signs of Temporomandibular Disorders were assessed according to clinical and occlusal examination and Research Diagnostic Criteria for Temporomandibular Disorders (TMD/RDC).

Results: A total of 173 men and 43 women were included in the study, with a mean age of $31.1 \pm 11$ years. The number of patients who applied to our clinic with pain was 142 (82.1\%). In the $54.3 \%$ of the patients, clicking was detected during the function. The most common type of parafunctional habits is clenching / bruxism with a rate of $34.7 \%$. In the study group, the mean value of the maximum unassisted mouth opening amount was calculated as $37 \pm 6.1 \mathrm{~mm}$. The average of the highest pain intensity experienced during the last 6 months was 6.29 out of 10 according to the Visual Analogue Scale (VAS). According to the Angle classification, 151 patients were classified as Class 1,14 as Class 2, and 8 as Class 3.

Conclusion: The rate of women in the group of patients who were referred with TMD was significantly higher. The most obvious symptoms are; pain, limitation in mandibular functions, and joint sounds. The frequency of TMD symptoms and findings was found to be quite high in our study. When the etiology of TMD is thought to be multifactorial, more work is needed to prevent TMD formation, to identify risk factors, and to determine the effectiveness of treatment modalities.

Keywords: Temporomandibular Joint; Temporomandibular Disorders; Research Diagnostic Criteria for Temporomandibular Disorders (TMD/RDC)
\end{abstract}

\section{Abbreviations}

TMD: Temporomandibular Disorders; TMD/RDC: Research Diagnostic Criteria for Temporomandibular Disorders; VAS: Visual Analogue Scale; TMJ: Temporomandibular Joint; SPSS: Statistical Package for Social Science

\section{Introduction}

Temporomandibular joint (TMJ) is one of the joints with the most complex structure in both morphological and functional aspects of the body [1]. Diseases and treatments of this complex structure have been debated for many years, and these disorders 
have been described in many different names over time. It is estimated that between $50 \%$ and $70 \%$ of the general population is affected from various disorders caused by the jaw joint region during a certain period of their lives [2].

Temporomandibular Disorders usually manifest with pain, joint sounds, limitation in mandibular movements and loss of function. In addition to these signs and symptoms, tenderness in chewing muscles, pain in adjacent anatomical regions of the jaw joint, earache, hearing loss, headache, dizziness can be seen in patients refereed to physicians [3-5].The complex relationship of the temporomandibular joint with other anatomical structures in the head and neck region and the diversity of symptoms in this region make it difficult for physicians to diagnose dysfunctions in joint disorders $[6,7]$.

Despite the many hypotheses on the causes of TMD, De Boever's multifactorial etiologic approach maintains its validity because of the lack of scientific resources to support them [8]. Joint hypermobility, occlusal abnormalities, trauma, bruxism, abnormal body posture, working in the wrong position and reading habits, stress, orthodontic treatment, dental procedures that will cause the mouth to remain open for a long time are among the factors that increase the susceptibility to these disorders $[9,10]$. Successful management of the TMD depends on identifying and controlling these factors [11].

Corresponding with temporomandibular joint disorders, many researchers have made very different classifications of each other, from the past to the present day, taking into account the etiological factors. The classification system established by Wilkes in 1989 and Bell in 1982 and modified by Okeson in 1998 is now widely known and used [12].

A detailed clinical examination for the correct diagnosis and treatment of temporomandibular disorders requires questioning of the etiologic factors that cause the disease. For this purpose, the use of reliable and valid questionnaires is important in order to determine the risk factors of the disease and to observe the change of the symptoms of the disease by storing it for long term $[3,13]$. In our study, we used the TMD / RDC form created in the lead of Samuel F. Dworkin and Linda Le Reche.

Our study was based on the examination of the results obtained by collecting and evaluating the data related to anamnesis, clinical findings, complaints and diagnoses of the patients who applied our clinic with Temporomandibular Disorders.

\section{Material and Method}

Patients included in our study were selected from among those over 18 years old who applied to Eskisehir Osman gazi University Faculty of Dentistry with complaints of Temporomandibular Disorder. After our work was planned, the application was done to Eskisehir Osman Gazi University Non-Interventional Clinical Research Ethics Committee Presidency and it was confirmed with ethical approval of the date 03.01.2016 with Decision No: 15.

In the clinical examination and evaluation stages of patients, the Turkish translation of the questionnaire, Temporomandibular Disorders / Research Diagnostic Criteria (TMD / RDC) form, prepared by Dworkin., et al. [14] was used. Anamnesis and examination forms used in our research, was taken from Dr. Pınar Kursoğlu's doctoral thesis entitled "Frequency and Distribution of Temporomandibular Disorders in Young Population" performedin 1999 at Istanbul University Health Sciences Institute, Prosthetic Dentistry Department [3].

Gender, age and education status of patients were also recorded in order to evaluate the demographic structure and social status of the group examined in our study. While assessing the pain in the temporomandibular region, the pain experienced is graded by the patient using the Visual Analogue Scale (VAS). During the clinical examination, the mouth opening way was detected and recorded as flat, deviated or deflected. The mouth opening capacities of the patients were obtained in mm by measuring with a caliper between the upper and lower cutters. Afterwards, by adding the amount of overbite to these values, painless unassisted mouth opening, maximum unassisted mouth opening and maximum assisted mouth opening amounts were calculated. (Figure 1 and 2) Eccentric jaw movements were also measured. (Figure 3) Temporal muscle, masseter muscle and joint area were evaluated by doublesided palpation and the patients were asked to rate the discomfort they felt from 0 to 3, 0: no, 1: slight, 2: moderate, 3: high. During the function or when the mouth is opened and closed, the presence of joint sounds is examined as 0 : no sound, 1: click, 2: crepitation. Occlusal examination was performed to assess the group of patients according to Angle classification, teeth missing, teeth closing at the posterior region, and functioning side contacts. 


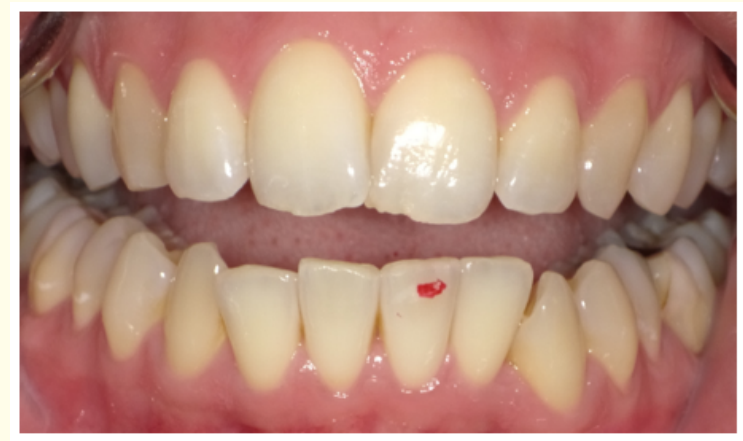

Figure 1: Overbite marking.

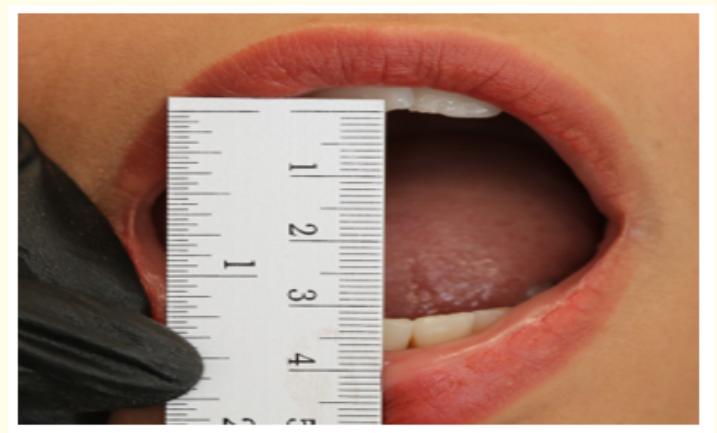

Figure 2: Measurement of mouth opening.

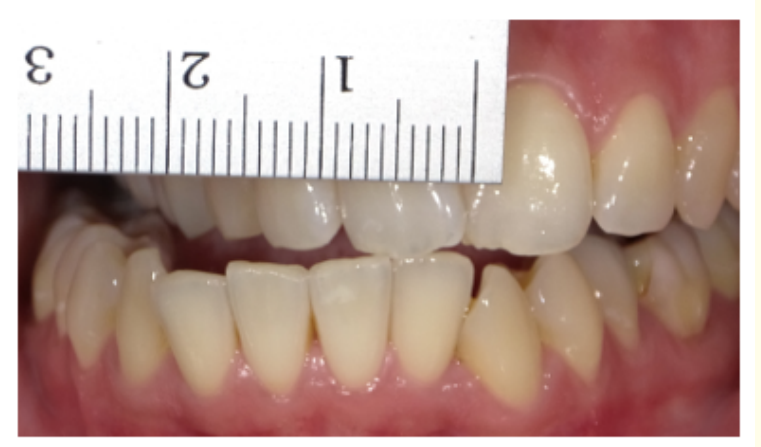

Figure 3: Measurement of lateral movements of the lower jaw.

Analysis of the data was made using Statistical Package for Social Science (SPSS) for Windows 21 package program. Descriptive statistical analyzes are shown as mean for continuous and intermittent numerical variables, standard deviation, median, minimum and maximum values. It was investigated by Shapiro Wilk test that continuous numerical variables from collected data exhibited normal distribution. In the variables that occurring normal distribution assumption, independent sample t-test was performed for comparison of independent binary groups and single direction variance analysis was performed for comparison of three or more independent groups. In the variables that are not occurring normal distribution assumption, Mann-Whitney-U was performed for comparison of independent binary groups and Kruskal Wallis analysis was performed for comparison of three independent groups. While examining qualitative data; the Fisher's Exact Test when the minimum expected value (tij) in the comparison of the independent two groups is smaller than 5 , the Continuity Correction test when $5<$ tij $<25$, and the Pearson ChiSquare test when tij> 25 was used.

Statistical significance level was evaluated as $\mathrm{p}<0.05$.

\section{Results}

Of the 173 patients who constituted our study group, 130 (75.1\%) were female and 43 (24.9\%) were male and ages ranged between 18 and 74 . The mean age of the women was 31.01 (18-74) while the mean age of the men was 31.41 (18 - 63), The mean age of all patients was 31.11 (Figure 4 and Table 1). 142 (82.1\%) of the patients reported pain in the joint area during the last month. The mean of the highest pain intensity experienced during the last 6 months was 6.29 out of 10 according to the VAS scale. (Figure 5)102 $(78.5 \%)$ of the females and $31(72.1 \%)$ of the males complained of sound from the jaw joints during functioning. However, this does not make a statistically significant difference between the genders. $(p=0.71) 125$ people reported lock or stuck that prevented them from opening the jaws fully. Among those who have stucking and locking problems, the proportion of women is very high and the difference between genders is statistically significant. $(p=0.029)$ (Table 2).

Of the 173 patients included in the study, $113(65.3 \%)$ were reported to have a clenching/ bruxism habit, while 12 (6.9\%) were recently exposed to physical trauma as a result of an injury on their face or jaw. $8(6.2 \%)$ of the patients that exposed to that kind of injury were women and 4 (9.3\%) were men. Women are more likely to be exposed to an impact than men. However, the difference between the genders in terms of trauma was not statistically significant. $(\mathrm{p}=0.72)$. 


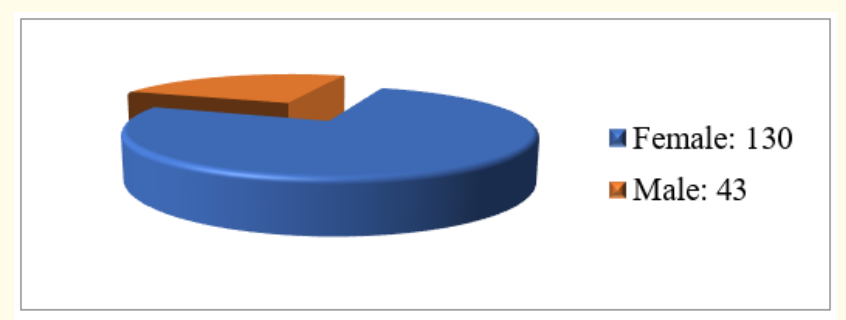

Figure 4: Distribution of Patients in the Research Group by Gender.

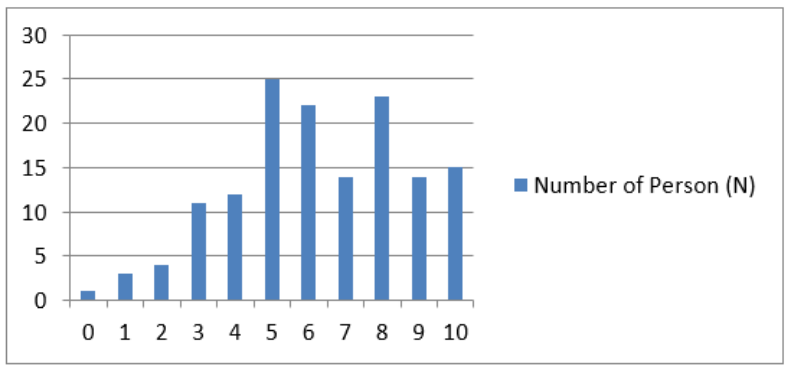

Figure 5: Distribution of the Severity of Pain in the Last 6 Months According to the VAS Scale.

\begin{tabular}{|l|c|c|c|c|c|c|}
\hline Gender & Number of Individuals & Average & Standarddeviation & StandardError & Minimum & Maximum \\
\hline Female & 130 & 31.0154 & 11.35132 & 0.99 & 18 & 74 \\
\hline Male & 43 & 31.4186 & 10.46589 & 1.59 & 18 & 63 \\
\hline Total & 173 & 31.1156 & 11.10931 & 0.84 & 18 & 74 \\
\hline
\end{tabular}

Table 1: Distribution of Patients in the Research Group by Age.

\begin{tabular}{|l|c|c|}
\hline \multirow{2}{*}{} & \multicolumn{2}{|c|}{ Number of Persons (N) /Percent (\%) } \\
\cline { 2 - 3 } & Yes & No \\
\hline Female & 100 & 30 \\
& $76.9 \%$ & $23.1 \%$ \\
\hline Total & 25 & 18 \\
& $58.1 \%$ & $41.9 \%$ \\
\hline
\end{tabular}

Table 2: TMJ locking problems of Distribution according to gender.

During the clinical examination, 133 patients (76.9\%) were able to open their mouths without deviation in the way of the mouth opening, 27 patients (15.6\%) deviated and 13 patients $(7.5 \%)$ had deflections.

In the group of patients examined, the mean value of painless unassisted mouth opening was $30 \pm 6.1 \mathrm{~mm}$, the mean value of maximum unassisted mouth opening average was $37 \pm 6.1 \mathrm{~mm}$ and the mean maximum assisted mouth opening amount was 41 $\pm 6.1 \mathrm{~mm}$. And when the mouth opening amounts are evaluated between the genders; it was seen that men had more mouth opening capacities than women with a statistically significant difference. ( $p$ $=0.57$ ) The mean amount of lateral movement in the community was measured as $6.8 \pm 1.2 \mathrm{~mm}$ for the right side, $6.9 \pm 1.3 \mathrm{~mm}$ for the left side and $4.9 \pm 1.6 \mathrm{~mm}$ for the protrusion movement.

According to Angle classification, 151 (87.3\%) of the patients were Class 1, $14(8.1 \%)$ and Class 2, 8 (4.6\%) were Class 3. (Figure 6) According to the occlusion guidance observed during lateral movements, 91 patients had canin-protective occlusion, 79 had group-function occlusion, and 3 had an occlusion other than these definitions. The distribution of teeth lost in the community is as shown in Table 3. Although the loss of teeth in the posterior region was thought to cause impairment of occlusal stability, the relationship between dental closing in the posterior region and pain felt in the face region was not found to be statistically significant. ( $p$ $=0.75$ ) 


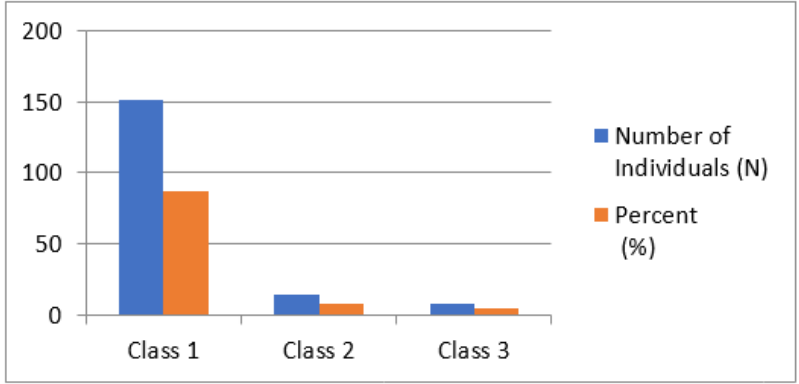

Figure 6: Distribution Chart According to Angle Classification.

\begin{tabular}{|l|c|c|c|c|}
\hline & $\begin{array}{c}\text { Mini- } \\
\text { mum }\end{array}$ & $\begin{array}{c}\text { Maxi- } \\
\text { mum }\end{array}$ & Average & $\begin{array}{c}\text { Standard } \\
\text { Deviation }\end{array}$ \\
\hline $\begin{array}{l}\text { MissingTooth- } \\
\text { Number }\end{array}$ & 0 & 8 & 0.26 & 1.149 \\
\hline $\begin{array}{l}\text { Number of } \\
\text { MissingTeeth in } \\
\text { AnteriorRegion }\end{array}$ & 0 & 13 & 1.40 & 2.493 \\
\hline $\begin{array}{l}\text { Number of } \\
\text { MissingTeeth in } \\
\text { PosteriorRegion }\end{array}$ & 0 & 21 & 1.66 & 3.262 \\
\hline
\end{tabular}

Table 3: Distribution According toTooth Deficiencies.

\section{Discussion}

Temporomandibular disorders; including temporomandibular joints, chewing muscles and many structures related to the anatomy of this region, a disorder causing jaw functions such as speech, eating-drinking, stretching, and chronic pain in the head and neck region [15-18].

The TMD / RDC form is based on the research systems used in the past, and takes its power from long-term epidemiological studies. Since 1992, many studies have been done on the validity and reliability of the TMD / RDC, and the efficiency and reliability in the recording of the patient group established has also been proved by other studies [13].

Studies of epidemiology of temporomandibular disorders have shown that symptoms occur more frequently in women than in men and most often in the period between the ages of 20 and 40 [19-22]. In parallel with the researches in the literature, the average age of the patients in our study is between 30-35 and the majority of the patients are women. Although it is said that the use of oral contraceptives and the use of exogenous estrogen in menopause do not affect temporomandibular joint dysfunction [23], some researchers have found that the reason for the high TMD findings in women compared with men is connected to hormonal changes, physiological reasons, connective tissue and muscle structure [24,25].

While pain in the joint area was considered to be one of the most obvious and unbearable findings of the disease [26,27], it was stated that the most common TMD findings in the research were joint sounds [28-30]. Studies show that the rate of showing at least one symptom of temporomandibular disorders varies between $30-78 \%$ [28-33]. Becauseour patients referred to us with pain and voice complaints in one or more joint areas, this rate was higher in our study than in other epidemiological studies.

Locker and Slade reported on a telephone survey of adults in Toronto that $9.5 \%$ of women and $5 \%$ of men reported pain in the frontal area of the ear [34]. In our study, 142 (82.1\%) of 173 patients were found to have pain in the face and frontal area of the ear in the last 1 month. The low rate of resemblance to other researches is due to our study on patients with complaints of joint pain.

It is argued that physical trauma has an initiating role in temporomandibular joint disorder, especially fracture and joint locking in the condyle area after acute trauma [35]. In our study group, 12 (6.9\%) patients had a physical trauma story. By sharing the same view with the literature, we think that physical trauma can damage the anatomical structures of the joint and disrupt the regular mechanism of functioning and initiate dysfunction.

Bruxism is a parafunctional habit known as tooth grinding or clenching, which is seen in high rates in individuals with TMD, considered among the etiologic factors of temporomandibular disorders [31,36,37]. Manfredini., et al. reported that myofascial pain and disc displacement were seen in $87.5 \%$ of patients with TMD and that $68.9 \%$ of these patients had a teeth clenching habit [30]. Another researcher reported this rate as 33.9\% among young people aged 18 - 25 [31]. Sipahi found teeth clenching in 152 and teeth grinding in 49 of 200 patients [38]. In the group of patients we examined, $34.7 \%$ reported that they have teeth clenching/ grinding habits. 
Although it is an important diagnostic factor, the limitations in mouth opening have been reported to be the least common clinical finding in studies [39]. This rate was found to be $9.8 \%$ in our study.

The frequency of deviations from the way of mouth opening in the form of a deviation and deflection varies between $20 \%$ and $45 \%$ in some investigations $[40,41]$. Consistent with the results of other studies, this rate was found to be $23.1 \%$ in our study.

Sensitivity to pain in temporomandibular joint region and chewing muscles in temporomandibular joint disorder is characteristic [15-17,42]. Bernhardt., et al. reported that palpation is also a susceptibility to the chewing muscles of patients with common jaw pain [43]. In our study, high sensitivity was found in 51 (29.5) patients' masseter muscle, 9 (5.2\%) patients' temporal muscle prefrontal region, 11 (6.3\%) patients' pterygoid EUs lateralis muscle and $20(11.5 \%)$ patients' pterygoid EUs medialis muscle. We think that the sensitivity of chewing muscles should be evaluated especially when the differential diagnosis of musclebased joint disorders is made.

Factors related to the development of temporomandibular joint dysfunction include; tooth loss, deterioration of the posterior closing mechanism, alteration of the closing relationship, and thus, changes in the vertical dimension, resulting in hyperactivity in the muscles $[15,39,40,44]$. Sarita., et al. suggested that patients with partial missing tooth and especially posterior tooth loss were susceptible to temporomandibular joint disease [45]. In our study, partial missing tooth was found in 53 (\% 30.6) of 173 patients and although there was no significant statistical relationship between teeth missing and the pain felt on the faces of the patients, it was observed that the teeth missing may be considered to be effective in the development of temporomandibular joint dysfunction.

Looking at the occlusal evaluations; although class II malocclusion, functional cross bite, open bite, collapsed bite, bent molar teeth, loss of centric relation do not directly active in the development of temporomandibular joint disorders, they have been suggested to increase disease symptoms by making an orthopedic effect on TMJ $[40,41,46,47]$. In our study, when we evaluated the closing associations in the clinical examinations of patients, TMJ was not statistically significant with the pain and voice even though there was a deep collapsed bite in 16 patients.
Despite the ability to adapt and tolerate trauma in the chewing system, occlusal disturbances can cause changes in this system and reveal TMJ irregularities $[2,48]$.

\section{Conclusion}

A detailed clinical examination for the correct diagnosis and treatment of temporomandibular disorders requires questioning of the etiologic factors that cause the disorder. For this purpose, the use of reliable and valid questionnaires is important in order to learn the risk factors of the disorder and to observe the change of the symptoms of the disorder by storing it for long term.

The adoption of a multidisciplinary approach in the treatment of temporomandibular disorders with complex etiology will enhance treatment success. Further work is needed to determine the risk factors associated with these conditions in order to prevent TMD formation and to personalize the treatment options for the patient.

\section{Declarations}

\section{Ethics committee approval form}

The name of the ethics committee that approved the study: Eskisehir Osman Gazi University Presidency of Non-Interventional Clinical Research Ethics Committee

\section{Bibliography}

1. Aksoy S and Orhan K. "Temporomandibular eklem görüntüleme yöntemleri”. Ondokuz Mayıs Üniversitesi Diş Hekimliği Fakültesi Dergis 11.2 (2010): 69-78.

2. Gray R and Al-Anı Z. "Temporomandibular Disorders: A Problem-Based Approach”. Çeviri: Kurt H. Temporomandibular Bozukluklar Problem Bazlı Yaklaşım, 1. Baskı. İstanbul, Medya Yayın Grubu, (2016):1-3.

3. Kursoğlu P. "Genç Popülasyonda Temporomandibular Rahatsızlıkların Sıklığı ve Dağılımı. Sağlık Bilimleri Enstitüsü, Protetik Diş Tedavisi Anabilim Dalı". DoktoraTezi, İstanbul: İstanbul Üniversitesi, (1999).

4. Demirkol N., et al. "Temporomandibular eklem rahatsızlıklarında düşük dozla tedavisinin kullanımı”. Gaziantep Medical Journal 21.3 (2015): 205-210.

5. Bagis B., et al. "Gender Difference in Prevalence of Signs and Symptoms of Temporomandibular Joint Disorders: A Retrospective Study on 243 Consecutive Patients". International Journal of Medical Sciences 9 (2012): 53944. 
6. Tozoglu S., et al. "Erzurum ve Çevresinden TME Rahatsızlığı Nedeniyle Kliniğimize Başvuran Hastaların Retrospektif İncelenmesi”. Atatürk Üniversitesi Diş Hekimliği Fakültesi Dergisi 18.3 (2008): 90-93.

7. Dalkız Mand Beydemir B. "Temporomandibular hastalıklarının teşhis ve tedavi yöntemleri”. Gata Basımevi Ankara (2003): 112-197.

8. De Boever JA. "Functional disturbances of the temporomandibular joint”. In: G.A. Zarb, G.E. Carlsson, eds. Temporomandibular Joint Function and Dysfunction Copenhagen: Munksgaard (1979): 193-214.

9. Keskin H., et al. "Temporomandibular Eklem/Ağrı Disfonksiyon Sendromunda Multidisipliner Yaklaşımlar. Keskin $\mathrm{H}$, Özdemir T, Tuncer N, Aksoy C. Gnatoloji. 1. Baskı". İstanbul: İstanbul Üniversitesi (1997): 35-37.

10. Yengin E. “Çiğneme Sistemi Bozukluklarında Etyoloji. Yengin E, Temporomandibular Rahatsızlıklarda Teşhis ve Tedavi”. 1. Baskı. İstanbul: İ.Ü. Diş Hekimliği Fakültesi Yayınları (2000): 41-56.

11. Chisnoiu A., et al. "Factors involved in the etiology of temporomandibular disorders- A literature review". Clujul Medical 88.4 (2015): 473-478.

12. Güneş 0. "Temporomandibular Eklem İnternal Bozukluklarında Minimal İnvaziv Tedavinin Etkileri Üzerine Retrospektif Bir Araştırma”. Ankara Üniversitesi Sağlık Bilimleri Enstitüsü, AğızDiş Çene Cerrahisi Anabilim Dalı, DoktoraTezi, Ankara (2015).

13. Kurt H., et al. “Temporomandibular Rahatsızlıkların Teşhisinde Temporomandibular Rahatsılıklar/Araştırma Teşhis Kriterlerinin (TMR/ATK) Kullanımı". İ.Ü. Diş. Hek. Fak. Derg. 40 (2006): 1-2.

14. Dworkin SF and LeResche L. "Research Diagnostic Criteria for Temporomandibular Disorders: Review Criteria, Examinations and Spesifi cations, Critique". Journal of Craniomandibular Disorders: Facial and Oral Pain 6.4 (1992): 301-355.

15. Brin MF., et al. "Botulinum toxin type A botox for pain and headache. Scientific and Therapeutic Aspects of Botulinum Toxin edited by Brin M.F, Jankovic J, Hallet M". Lippincott Williams and Wilkins, Philadelphia (2002): 233-250.

16. Hotta TH., et al. "Combination therapies in the treatment of temporomandibular disorders: A clinical report". Journal of Prosthetic Dentistry 89 (2003): 536-539.
17. Okeson JP. “Treatment of temporomandibular joint disorders. Management of temporomandibular disorders and occlusion. Mos by Year Book. Third Edition. (1993): 403-436.

18. Schwartz $M$ and Freund B. "Botulinum toxin A the rapy for temporomandibular disorders". Scientific and therapeutic aspects of botulinum toxin edited by Brin MF, Jankovic J, Hallet M. Lippincott Williams and Wilkins, Philadelphia (2002): 259268.

19. Emshoff R., et al. "Effect of temporomandibular joint arthrocentesis on synovial fluidmediatorlevel of tum or necrosis factor- $\alpha$ : implications for treatment outcome". International Journal of Oral and Maxillofacial Surgery 29.3 (2000): 176-182.

20. Hancı M., et al. "Intra-articular platelet-rich plasma injection for the treatment of temporomandibular disorders and a comparison with arthrocentesis". Journal of Cranio-Maxillofacial Surgery 43 (2015): 162-166.

21. Bonjardim LR., et al. "Signs and aymptoms of temporomandibular disorders in adolescents". Brazilian Oral Research 19.2 (2005): 93-98.

22. Öz kaynak Ö. “Temporomandibuler eklem içsel düzensizliklerinde artrosentez uygulamalarının rolü ve etkileri. Sağlık Bilimleri Enstitüsü, Protetik Diş Tedavisi Anabilim Dalı". Doktora Tezi, Ankara: Ankara Üniversitesi, (2006).

23. Hatch JP., et al. "Is use of exogen ausestrogen associated with temporomandibular signs and symptoms". JADA 132 (2001): 319-326.

24. Nomura K., et al. "Use of the Fonseca's Question naireto Assess the Prevalance and Severity of Temporomandibular Disorders in Brazilian Dental Under graduates". Brazilian Dental Journal 18 (2007):163-167.

25. Babadağ M., et al. "Pre-and posttreatment analysis of clinical symptoms of patient with temporomandibular disorders". Quintessence International 35.10 (2004): 811-814.

26. Reston JT and Turkelson CM. "Meta-analysis of surgical treatments for temporomandibular articular disorders". Journal of Oral and Maxillofacial Surgery 61 (2003): 3-10.

27. Emshoff R., et al. "Relative odds of temporomandibular joint pain as a function of magnetic resonance imaging findings of internal derangement, osteoarthrosis, effusion, and bone marrowedema". Oral Surgery, Oral Medicine, Oral Pathology, and Oral Radiology 95 (2003): 437-445. 
28. Yekkalam N and Wanman A. "Prevalence of signs and symptom sindicative of temporomandibular disorders and headaches in 35-, 50-, 65- and 75-year-olds living in Västerbotten, Sweden". Acta Odontologica Scandinavica 72 (2014): 458-465.

29. Fernandes G., et al. "Association between painful temporomandibular disorders, sleep bruxism and tinnitus". Brazilian Oral Research 28.3 (2014).

30. Manfredini D., et al. "Prevalence of bruxism in patients with different research diagnostic criteria for temporomandibular disorders (RDC/TMD) diagnoses". Cranio 21.4 (2003): 279285.

31. Şener S., et al. "Genç yetişkin bireylerde bruksizm farkındalığı ve ilişkili değișik faktörlerin değerlendirilmesi". Cumhuriyet Dental Journal 17 (2012): 4.

32. Bader G and Lavigne G. "Sleep bruxism an overview of an oromandibular sleep movement disorder. Review article". Sleep Medicine Reviews 4.1 (2000): 27-43.

33. Oral K., et al. "Etiology of temporomandibular disorder pain". The Journal of Turkish Society of Algology 21.3 (2009): 89-94.

34. Locker D and Slade G. "Prevalence of symptoms associated with temporomandibular disorders in a Canadian population". Community Dentistry and Oral Epidemiology 16 (1988): 310-313.

35. American Society of Temporomandibular Joint Surgeons. "Guidelines for diagnosis and management of disorders involving the temporomandibular joint and elated musculoskeletal structures". Cranio 21.1 (2003): 68-76.

36. Clark GT and Ram S. "Four oral motor disorders: bruxism, dystonia, dyskinesia and drug-induced dystonic extrapyramidal reactions". Dental Clinics of North America 51 (2007): 225-243.

37. Wieckiewicz M., et al. "Prevalence and Correlation between TMD Based on RDC/TMD Diagnoses, Oral Parafunctions and Psychoemotional Stress in Polish University Students". Bio Med Research International (2014): 472346.

38. Sipahi A. "Temporomandibular Eklem Disfonksiyonlu Hastalarda Uygulanan Değişik Tedavi Yöntemlerinin Karşılaştırılması. Ege Üniversitesi Sağlık Bilimleri Enstitüsü, Ağız Diş ve Çene Hastalıkları Cerrahisi Programı, DoktoraTezi, İzmir (2006).
39. Hilaire H., et al. "Clinico pathologic conference: Trismus following dental treatment". Oral Surgery, Oral Medicine, Oral Pathology, and Oral Radiology 98 (2004): 261-266.

40. Zanoteli E., et al. "Temporomandibular joint and masticatory muscle involvement in myotonic dystrophy: A study by magnetic resonance imaging". Oral Surg Oral Med Oral Pathol Oral Radiol Endod 94 (2002): 262-271.

41. Egermark I., et al. "A 20year follow-up signs and symptoms of temporomandibular disorders and malocclusions in subjects with and without orthodontic treatment in childhood". The Angle Orthodontist 73.2 (2003): 109-115.

42. Saruhan oğlu CS. "Kișilik Özelliklerinin Temporomandibular Eklem Hastalıkları Üzerine Etkisi. Sağlık Bilimleri Enstitüsü, Protetik Diş Tedavisi Anabilim Dalı". Doktora Tezi, İstanbul: İstanbul Üniversitesi (2014).

43. Bernhardt O., et al. "Risc factors for headache, including TMD signs and symptoms, and their impact on quality of life. Results of the study of health in pomerania (SHIP)". Quintessence International 36 (2005): 55-64.

44. Tallents RH., et al. "Prevalence of missing posterior teeth and intraarticular temporomandibular disorders". Journal of Prosthetic Dentistry 87.1 (2002): 45-50.

45. Sarita PT., et al. "Signs and symptoms associated with TMD in adults with shortened dentalarches". The International Journal of Prosthodontics 16.3 (2003): 265-270.

46. Henrikson T., et al. "Symptoms and signs of temporomandibular disorders in girls with normal occlusion and class II malocclusion". Acta Odontologica Scandinavica 55.4 (1997): 229235.

47. Thilander B., et al. "Prevalence of temporomandibular dysfunction and itsassociation with malocclusion in children and adolescents; an epidemiologic study related to specified stages of dental development". The Angle Orthodontist 72.2 (2002): 146-154.

48. Pergamalian A., et al. "The association between wear facets, bruxism, and severity of facial pain in patients with temporomandibular disorders". Journal of Prosthetic Dentistry 90 (2003): 194-200.

Volume 3 Issue 11 November 2019

(C) All rights are reserved by Emre Mumcu and Merve Kayis. 